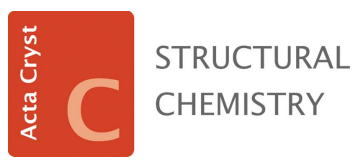

ISSN 2053-2296

Received 30 October 2019

Accepted 4 February 2020

Edited by V. Langer, Chalmers University of Technology, Sweden

Keywords: magnesium; carbonate; lowtemperature hydrate; Raman spectroscopy; crystal structure.

CCDC reference: 1981730

Supporting information: this article has supporting information at journals.iucr.org/C

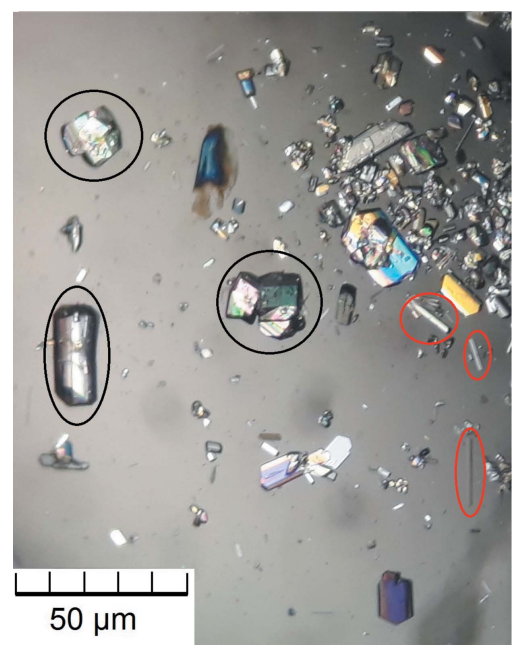

OPEN ஓ ACCESS

\section{A new hydrate of magnesium carbonate, $\mathrm{MgCO}_{3} \cdot 6 \mathrm{H}_{2} \mathrm{O}$}

\author{
Christine Rincke, ${ }^{*}$ Horst Schmidt and Wolfgang Voigt
}

Institute of Inorganic Chemistry, TU Bergakademie Freiberg, Leipziger Strasse 29, D-09599 Freiberg, Germany. *Correspondence e-mail: christine.rincke@chemie.tu-freiberg.de

During investigations of the formation of hydrated magnesium carbonates, a sample of the previously unknown magnesium carbonate hexahydrate $\left(\mathrm{MgCO}_{3}\right.$. $6 \mathrm{H}_{2} \mathrm{O}$ ) was synthesized in an aqueous solution at $273.15 \mathrm{~K}$. The crystal structure consists of edge-linked isolated pairs of $\mathrm{Mg}\left(\mathrm{CO}_{3}\right)\left(\mathrm{H}_{2} \mathrm{O}\right)_{4}$ octahedra and noncoordinating water molecules, and exhibits similarities to $\mathrm{NiCO}_{3} \cdot 5.5 \mathrm{H}_{2} \mathrm{O}$ (hellyerite). The recorded X-ray diffraction pattern and the Raman spectra confirmed the formation of a new phase and its transformation to magnesium carbonate trihydrate $\left(\mathrm{MgCO}_{3} \cdot 3 \mathrm{H}_{2} \mathrm{O}\right)$ at room temperature.

\section{Introduction}

In the $\mathrm{MgO}-\mathrm{H}_{2} \mathrm{O}-\mathrm{CO}_{2}$ system, besides the thermodynamically stable $\mathrm{MgCO}_{3}$ (magnesite), a variety of hydrated magnesium carbonates are known, which can be divided in basic magnesium carbonates, containing $\mathrm{OH}^{-}$ions $\left[\mathrm{Mg}_{5}\left(\mathrm{CO}_{3}\right)_{4}\right.$ $(\mathrm{OH})_{2} \cdot n \mathrm{H}_{2} \mathrm{O}$ and $\left.\mathrm{Mg}\left(\mathrm{CO}_{3}\right)(\mathrm{OH})_{2} \cdot n \mathrm{H}_{2} \mathrm{O}\right]$, and neutral magnesium carbonates with the composition $\mathrm{MgCO}_{3} \cdot n \mathrm{H}_{2} \mathrm{O}$ (Hopkinson et al., 2012; Jauffret et al., 2015). All these phases are of significant relevance in various technological processes, in geological explorations, mineral conversion in the sequestration of $\mathrm{CO}_{2}$ and in biomineralization (Chaka \& Felmy, 2014). Nevertheless, there are many open questions with respect to the conditions of formation, the characterization, the crystal structure and the stability of higher hydrated neutral magnesium carbonates (Hänchen et al., 2008; Hopkinson et al., 2012; Rincke, 2018).

The most frequently investigated neutral magnesium carbonate hydrate, $\mathrm{MgCO}_{3} \cdot 3 \mathrm{H}_{2} \mathrm{O}$ (mineral name: nesquehonite), can be synthesized in the temperature range between 283.15 and 325.15 K (Giester et al., 2000; Frost \& Palmer, 2011; Jauffret et al., 2015; Hänchen et al., 2008; Gloss, 1937; Takahashi \& Hokoku, 1927; Hopkinson et al., 2012).

At lower temperatures, the pentahydrate, i.e. $\mathrm{MgCO}_{3} \cdot 5 \mathrm{H}_{2} \mathrm{O}$ (mineral name: lansfordite), is known. Its crystal structure (monoclinic space group $P 2_{1} / m$ ) was determined by Liu et al. (1990) from a synthetic sample and by Nestola et al. (2017) from a mineral. Several possibilities are described to synthesize lansfordite (Ming \& Franklin, 1985; Liu et al., 1990). In order to obtain large prismatic crystals, $\mathrm{CO}_{2}$ can be bubbled through an aqueous suspension of $\mathrm{MgO}$ and, subsequently, the crystallization can be carried out in the filtered solution at low temperature (Liu et al., 1990). However, the authors (Liu et al., 1990) did not provide information about the exact $\mathrm{CO}_{2}$ pressure, the regime of temperature, the concentration of magnesium ions in the solution and the time needed for crystallization. According to Ming \& Franklin (1985), these factors are important to avoid the formation of nesquehonite. 
Table 1

Experimental details.

\begin{tabular}{|c|c|}
\hline Crystal data & \\
\hline Chemical formula & $\mathrm{MgCO}_{3} \cdot 6 \mathrm{H}_{2} \mathrm{O}$ \\
\hline$M_{\mathrm{r}}$ & 192.42 \\
\hline Crystal system, space group & Orthorhombic, Pbam \\
\hline Temperature $(\mathrm{K})$ & 200 \\
\hline$a, b, c(\AA)$ & $\begin{array}{l}12.3564(18), 6.5165(7) \\
9.9337(11)\end{array}$ \\
\hline$V\left(\AA^{3}\right)$ & $799.87(17)$ \\
\hline$Z$ & 4 \\
\hline Radiation type & Мо $K \alpha$ \\
\hline$\mu\left(\mathrm{mm}^{-1}\right)$ & 0.24 \\
\hline Crystal size (mm) & $0.7 \times 0.55 \times 0.15$ \\
\hline Data collection & \\
\hline Diffractometer & Stoe IPDS $2 \mathrm{~T}$ \\
\hline Absorption correction & Integration (Coppens, 1970) \\
\hline$T_{\min }, T_{\max }$ & $0.694,0.887$ \\
\hline $\begin{array}{l}\text { No. of measured, independent and } \\
\text { observed }[I>2 \sigma(I)] \text { reflections }\end{array}$ & $8319,1143,965$ \\
\hline$R_{\text {int }}$ & 0.036 \\
\hline$(\sin \theta / \lambda)_{\max }\left(\AA^{-1}\right)$ & 0.687 \\
\hline Refinement & \\
\hline$R\left[F^{2}>2 \sigma\left(F^{2}\right)\right], w R\left(F^{2}\right), S$ & $0.029,0.085,1.18$ \\
\hline No. of reflections & 1143 \\
\hline No. of parameters & 83 \\
\hline $\mathrm{H}$-atom treatment & All H-atom parameters refined \\
\hline$\Delta \rho_{\max }, \Delta \rho_{\min }\left(\mathrm{e} \mathrm{A}^{-3}\right)$ & $0.23,-0.26$ \\
\hline
\end{tabular}

Computer programs: X-AREA (Stoe \& Cie, 2015), X-RED (Stoe \& Cie, 2015), SHELXS97 (Sheldrick, 2008), SHELXL2016 (Sheldrick, 2015), DIAMOND (Brandenburg, 2017) and publCIF (Westrip, 2010).

Furthermore, the solubility of lansfordite is highly dependent on temperature and on $\mathrm{CO}_{2}$ pressure (Königsberger et al., 1999; Takahashi \& Hokoku, 1927; Rincke, 2018). Besides that, there are contradictory statements about the temperature and the rate of conversion of the pentahydrate to the trihydrate. Some research groups have recorded a transition temperature between 283.15 and $288.15 \mathrm{~K}$ (Takahashi \& Hokoku, 1927; Gloss, 1937; Yanaťeva \& Rassonskaya, 1961; Hill et al., 1982;
Langmuir, 1965; Ming \& Franklin, 1985), while others observed the stability of synthesized and natural samples of lansfordite at room temperature over a period of a few months (Liu et al., 1990; Nestola et al., 2017). Neutral magnesium carbonates with a water content greater than five units per formula are not known up to now. Such highly hydrated neutral carbonates of other bivalent metal ions have been found only for calcium, i.e. $\mathrm{CaCO}_{3} \cdot 6 \mathrm{H}_{2} \mathrm{O}$ (ikaite; Hesse et al., 1983), and nickel, i.e. $\mathrm{NiCO}_{3} \cdot 5.5 \mathrm{H}_{2} \mathrm{O}$ (hellyerite; Bette et al., 2016). Our own investigations should elucidate the conditions of formation of the magnesium carbonate hydrates.

\section{Experimental}

\subsection{Synthesis and crystallization}

To obtain crystals of $\mathrm{MgCO}_{3} \cdot 6 \mathrm{H}_{2} \mathrm{O}$ suitable for singlecrystal diffraction analysis (see V11 in Table S1 of the supporting information), carbon dioxide was bubbled through a suspension of magnesium oxide in deionized water $(3.1 \mathrm{~g}$, Magnesia M2329, p.a.) for $22 \mathrm{~h}$ at $273.15 \mathrm{~K}$. After that, the solution was filtered and stored without stirring at $273.15 \mathrm{~K}$ for $16 \mathrm{~d}$ until the product crystallized. The product was filtered off for characterization by powder X-ray diffraction and Raman spectroscopy. For intensity data collection, a prismatic crystal of $\mathrm{MgCO}_{3} \cdot 6 \mathrm{H}_{2} \mathrm{O}$ was recovered from a droplet of its mother liquor and mounted rapidly in the cold $(200 \mathrm{~K})$ stream of nitrogen gas of the diffractometer.

\subsection{Powder X-ray diffraction}

The powder X-ray diffraction (PXRD) patterns were taken for phase identification with a Bruker D8 Discover laboratory powder diffractometer in the Bragg-Brentano set-up $\left(\mathrm{Cu} K \alpha_{1}\right.$ radiation, Vantec 1 detector). The samples were prepared as

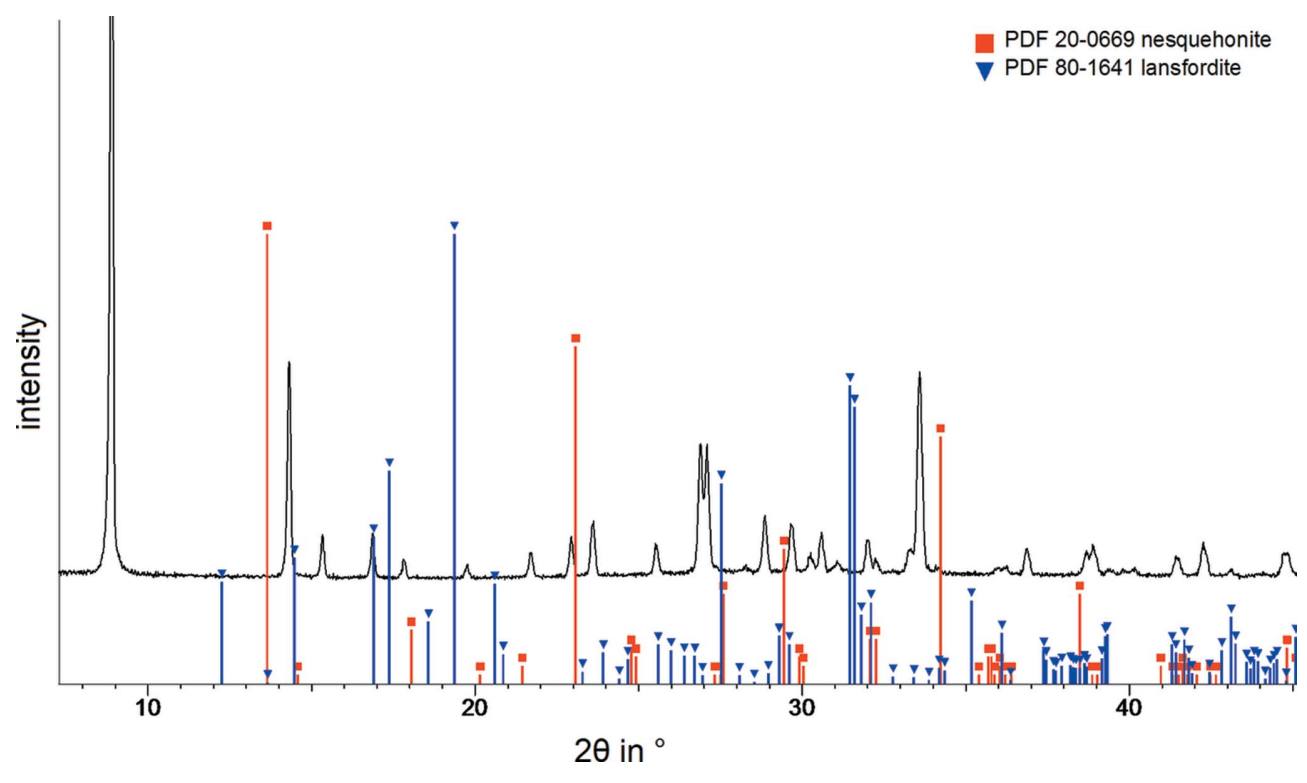

Figure 1

$2 \theta$ in $^{\circ}$

Powder XRD pattern of $\mathrm{MgCO}_{3} \cdot 6 \mathrm{H}_{2} \mathrm{O}$ at low temperature $\left(\sim 273.15 \mathrm{~K}, \mathrm{Cu} K \alpha\right.$ radiation) and reference data for $\mathrm{MgCO}_{3} \cdot 3 \mathrm{H}_{2} \mathrm{O}\left(\mathrm{PDF}^{20-0669)}\right.$ and $\mathrm{MgCO}_{3} \cdot 5 \mathrm{H}_{2} \mathrm{O}$ (PDF 80-1641). 


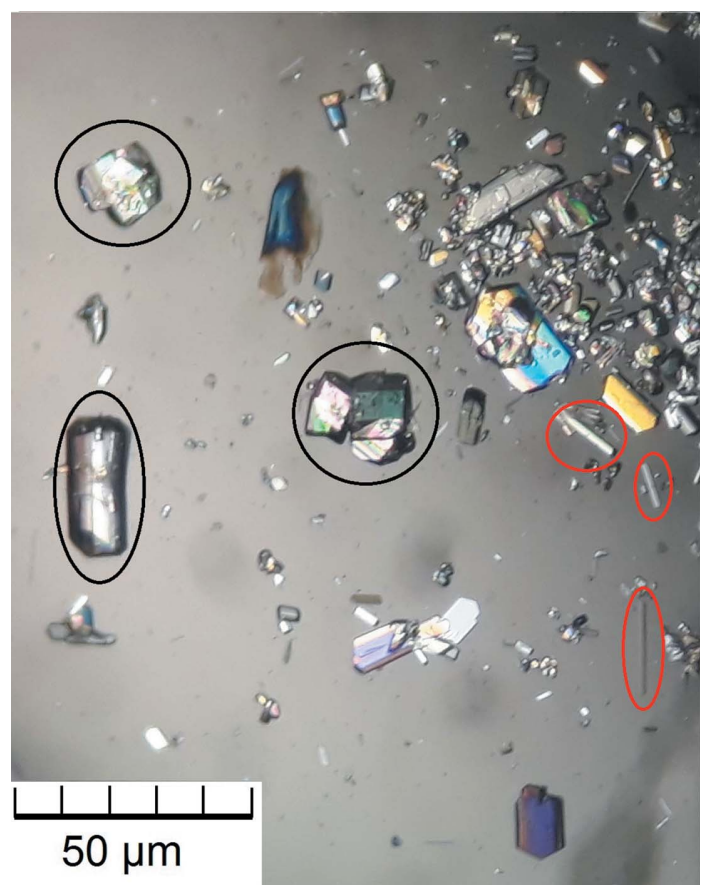

Figure 2

Microscopic image of prismatic $\mathrm{MgCO}_{3} \cdot 6 \mathrm{H}_{2} \mathrm{O}$ crystals (framed in black) which are partly intergrown. The red-framed crystals are the typical needles of the transformation product $\mathrm{MgCO}_{3} \cdot 3 \mathrm{H}_{2} \mathrm{O}$.

flat plates and measured at low temperatures (about 273.15 K) with a home-made cooling box (Rincke, 2018).

\subsection{Raman spectroscopy}

The Raman spectra were recorded shortly after synthesis with a Bruker RFS100/S FT spectrometer at room temperature $(\mathrm{Nd} / \mathrm{YAG}$ laser, wavelength of the laser $=1064 \mathrm{~nm})$.

\subsection{Refinement}

Crystal data, data collection and structure refinement details are given in Table 1 . The positions of the $\mathrm{H}$ atoms could be located from residual electron-density maxima after further refinement and were refined isotropically.

\section{Results and discussion}

\subsection{Conditions of formation and characterization of magnesium carbonate hexahydrate}

On the basis of the information of Liu et al. (1990) for the formation of lansfordite, $\mathrm{CO}_{2}$ was bubbled through aqueous $\mathrm{MgO}$ suspensions with various concentrations. After filtration of the solution, the product crystallized at low temperature $(273.15-278.15 \mathrm{~K})$, while the $\mathrm{CO}_{2}$ pressure was decreased by slow degassing of the $\mathrm{CO}_{2}$ and the solubility product of the carbonate was exceeded. The detailed experimental conditions are given in the supporting information (see Table S1). Characterization of the product with PXRD revealed that nesquehonite is formed at low $\mathrm{MgO}$ concentrations, while an unknown phase crystallizes from the solutions at higher $\mathrm{Mg}^{2+}$ concentrations, near the solubility of lansfordite at $p\left(\mathrm{CO}_{2}\right)=$
Table 2

Selected geometric parameters $\left(\AA,^{\circ}\right)$.

\begin{tabular}{|c|c|c|c|}
\hline $\mathrm{Mg} 1-\mathrm{O} 1$ & $2.1043(8)$ & $\mathrm{C} 1-\mathrm{O} 4$ & $1.2840(11)$ \\
\hline $\mathrm{Mg} 1-\mathrm{O} 2$ & $2.0859(8)$ & $\mathrm{C} 1-\mathrm{O} 1$ & $1.2978(17)$ \\
\hline $\mathrm{Mg} 1-\mathrm{O} 3$ & $2.0672(8)$ & & \\
\hline $\mathrm{O} 3-\mathrm{Mg} 1-\mathrm{O} 2$ & $86.12(3)$ & $\mathrm{O} 1-\mathrm{Mg} 1-\mathrm{O}^{\mathrm{ii}}$ & $81.25(5)$ \\
\hline $\mathrm{O} 2-\mathrm{Mg} 1-\mathrm{O} 2^{\mathrm{i}}$ & $95.28(5)$ & $\mathrm{O} 4-\mathrm{C} 1-\mathrm{O} 4^{\mathrm{iii}}$ & $120.41(13)$ \\
\hline $\mathrm{O} 3-\mathrm{Mg} 1-\mathrm{O} 1$ & $91.46(4)$ & $\mathrm{O} 4-\mathrm{C} 1-\mathrm{O} 1$ & $119.79(6)$ \\
\hline $\mathrm{O} 2-\mathrm{Mg} 1-\mathrm{O} 1$ & $91.74(3)$ & $\mathrm{Mg} 1-\mathrm{O} 1-\mathrm{Mg} 1^{\mathrm{ii}}$ & $98.75(5)$ \\
\hline
\end{tabular}

Symmetry codes: (i) $-x+1,-y, z$; (ii) $-x+1,-y,-z+1$; (iii) $x, y,-z+1$.

1 bar $\left[\mathrm{m}\left(\mathrm{Mg}^{2+}\right)=0.386 \mathrm{~mol} \mathrm{~kg}{ }^{-1}\left(\mathrm{H}_{2} \mathrm{O}\right)\right.$ at $\left.273.15 \mathrm{~K}\right]$ (Königsberger et al., 1999; Rincke, 2018). Fig. 1 shows the PXRD pattern of the new product phase in comparison with the reference data for $\mathrm{MgCO}_{3} \cdot 3 \mathrm{H}_{2} \mathrm{O}$ and $\mathrm{MgCO}_{3} \cdot 5 \mathrm{H}_{2} \mathrm{O}$. The composition of this unknown phase was determined by singlecrystal diffraction as $\mathrm{MgCO}_{3} \cdot 6 \mathrm{H}_{2} \mathrm{O}$. The pentahydrate was not found in our investigations.

Large prismatic crystals of $\mathrm{MgCO}_{3} \cdot 6 \mathrm{H}_{2} \mathrm{O}$ were obtained while using a longer time of crystallization of $16 \mathrm{~d}$ (see V11 in Table S1 of the supporting information). These crystals, which are partly intergrown, convert in a few minutes at room temperature into the typical needles of $\mathrm{MgCO}_{3} \cdot 3 \mathrm{H}_{2} \mathrm{O}$ (Fig. 2). The process of phase transformation could also be seen by means of Raman spectroscopy (Fig. 3). The assignments of the band positions in comparison with the spectra of nesquehonite and lansfordite are given in the supporting information (Table S2).

\subsection{Crystal structure of magnesium carbonate hexahydrate}

Magnesium carbonate hexahydrate crystallizes in the orthorhombic space group Pbam (No. 55). The Mg1 atom is located on a twofold axis of symmetry. Atoms $\mathrm{C} 1, \mathrm{O} 1$ and $\mathrm{O} 5$, and the water molecule $\mathrm{H} 6 A-\mathrm{O} 6-\mathrm{H} 6 B$ are positioned on a mirror plane.

Isolated pairs of edge-linked $\mathrm{Mg}\left(\mathrm{CO}_{3}\right)_{2}\left(\mathrm{H}_{2} \mathrm{O}\right)_{4}$ octahedra are the main building blocks in the crystal structure (Fig. 4).

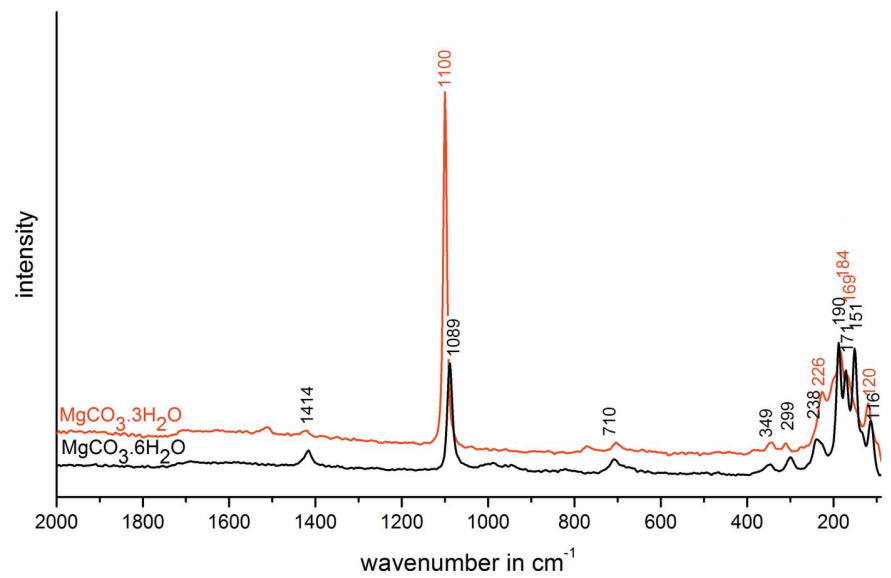

Figure 3

Raman spectrum of $\mathrm{MgCO}_{3} \cdot 6 \mathrm{H}_{2} \mathrm{O}$ (black) in comparison with the transformation product $\mathrm{MgCO}_{3} \cdot 3 \mathrm{H}_{2} \mathrm{O}$ (red) after storage at room temperature. 


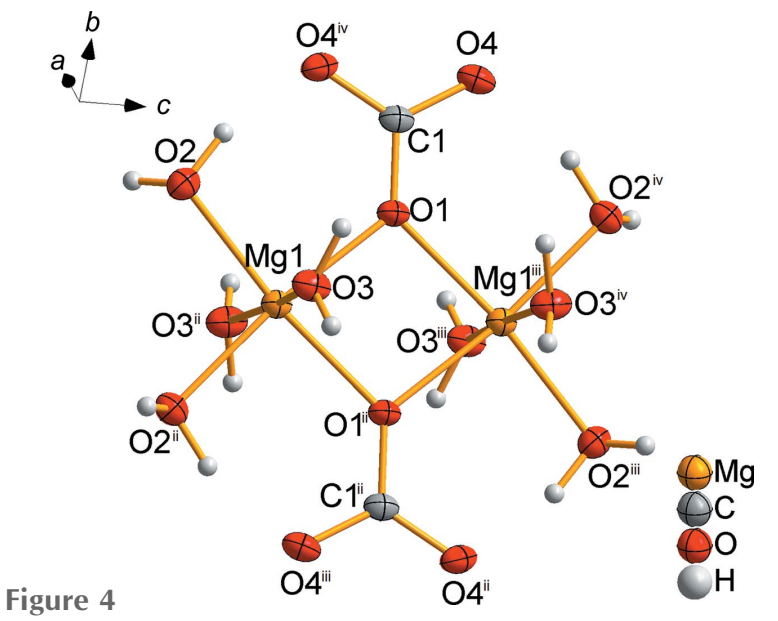

Illustration of the main building block in the crystal structure of $\mathrm{MgCO}_{3} \cdot 6 \mathrm{H}_{2} \mathrm{O}$, showing isolated pairs of edge-linked $\mathrm{Mg}\left(\mathrm{CO}_{3}\right)_{2}\left(\mathrm{H}_{2} \mathrm{O}\right)_{4}$ octahedra [symmetry codes: (ii) $-x+1,-y, z$; (iii) $-x+1,-y,-z+1$; (iv) $x, y,-z+1]$.
Table 3

Hydrogen-bond geometry $\left(\AA,^{\circ}\right)$.

\begin{tabular}{lllll}
\hline$D-\mathrm{H} \cdots A$ & $D-\mathrm{H}$ & $\mathrm{H} \cdots A$ & $D \cdots A$ & $D-\mathrm{H} \cdots A$ \\
\hline $\mathrm{O} 5-\mathrm{H} 5 \cdots \mathrm{O} 2^{\mathrm{iii}}$ & $0.812(18)$ & $2.068(19)$ & $2.8545(12)$ & $162.9(18)$ \\
$\mathrm{O}^{\mathrm{iii}}-\mathrm{H} 6 B \cdots \mathrm{O}^{\mathrm{iv}}$ & $0.87(3)$ & $1.93(3)$ & $2.7662(19)$ & $161(2)$ \\
$\mathrm{O}^{\mathrm{H}}-\mathrm{H} 6 A \cdots 5^{\mathrm{iv}}$ & $0.76(3)$ & $1.99(3)$ & $2.7137(19)$ & $160(3)$ \\
$\mathrm{O}-\mathrm{H} 3 B \cdots \mathrm{O} 4^{\mathrm{v}}$ & $0.788(19)$ & $2.025(19)$ & $2.8055(12)$ & $170.7(18)$ \\
$\mathrm{O} 3-\mathrm{H} 3 A \cdots \mathrm{O} 4^{\mathrm{vi}}$ & $0.93(2)$ & $1.77(2)$ & $2.7001(12)$ & $174.1(18)$ \\
$\mathrm{O} 2-\mathrm{H} 2 B \cdots \mathrm{O} 4^{\mathrm{iii}}$ & $0.92(2)$ & $1.70(2)$ & $2.5868(12)$ & $162(2)$ \\
$\mathrm{O} 2-\mathrm{H} 2 A \cdots \mathrm{O} 6$ & $0.84(2)$ & $1.91(2)$ & $2.7417(13)$ & $168.7(18)$ \\
\hline
\end{tabular}

Symmetry codes: (ii) $-x+1,-y,-z+1$; (iii) $x, y,-z+1$; (iv) $x+\frac{1}{2},-y+\frac{1}{2},-z+1$; (v) $x-\frac{1}{2},-y+\frac{1}{2},-z+1 ;(\mathrm{vi})-x+1,-y+1,-z+1$.

The crystal structure differs significantly from those of $\mathrm{MgCO}_{3} \cdot 3 \mathrm{H}_{2} \mathrm{O}$ and $\mathrm{MgCO}_{3} \cdot 5 \mathrm{H}_{2} \mathrm{O} ; \mathrm{MgCO}_{3} \cdot 3 \mathrm{H}_{2} \mathrm{O}$ exhibits a monoclinic crystal structure consisting of infinite chains along [010], formed by corner-sharing $\mathrm{MgO}_{6}$ octahedra and $\mathrm{CO}_{3}$ groups, which link three $\mathrm{MgO}_{6}$ octahedra by two common corners and one edge (Giester et al., 2000). In the monoclinic
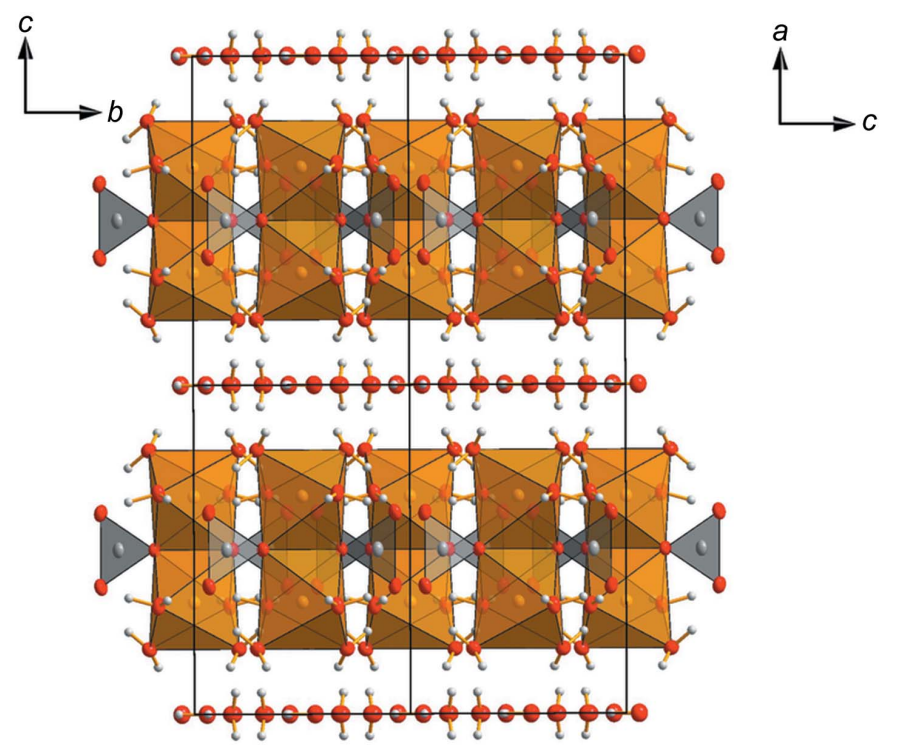

(a)
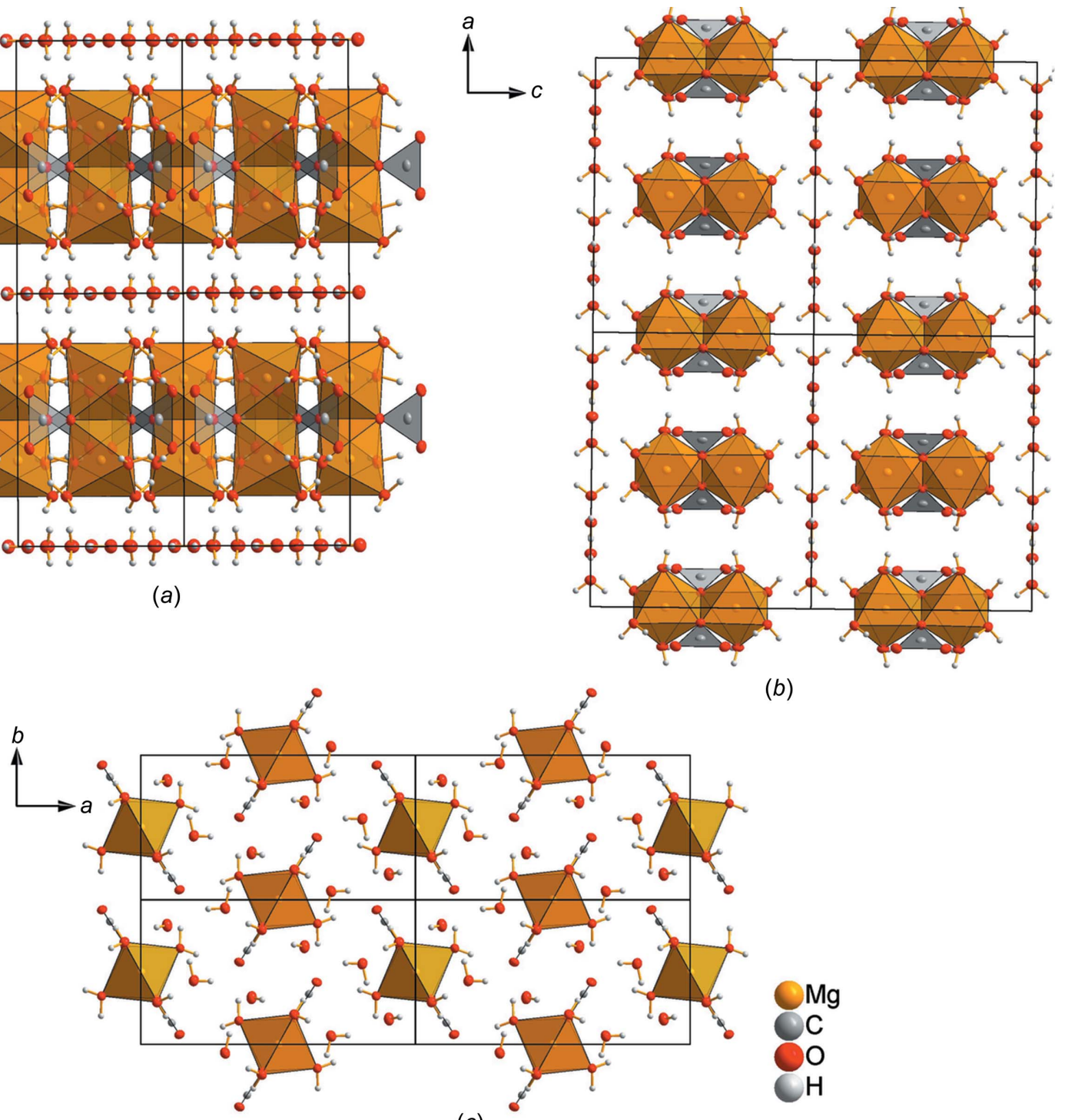

Figure 5

(c)

Projection of the crystal structure of $\mathrm{MgCO}_{3} \cdot 6 \mathrm{H}_{2} \mathrm{O}(a)$ in the $a$ direction, $(b)$ in the $b$ direction and $(c)$ in the $c$ direction. 


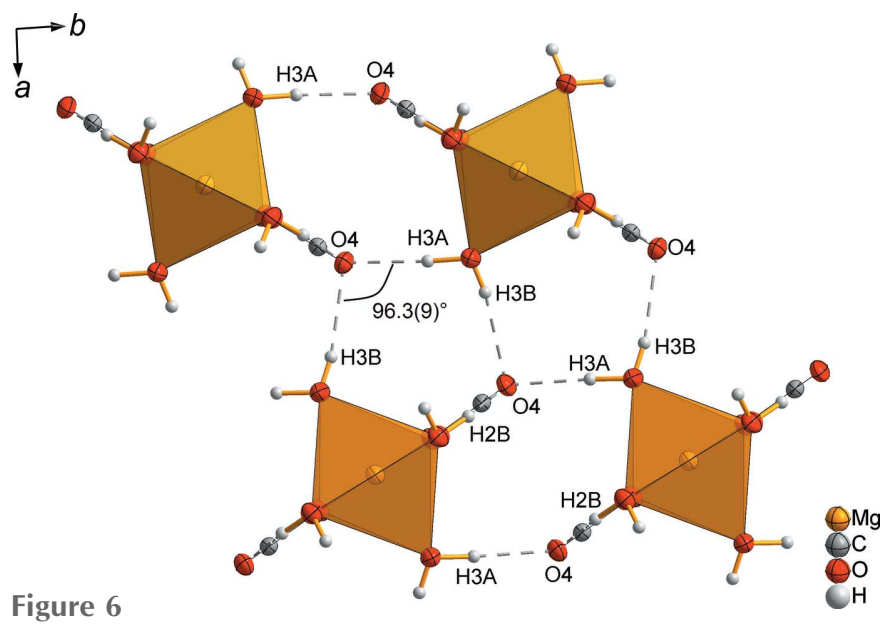

Part of the crystal structure of $\mathrm{MgCO}_{3} \cdot 6 \mathrm{H}_{2} \mathrm{O}$, showing the intralayer hydrogen bonds (dashed lines).

crystal structure of $\mathrm{MgCO}_{3} \cdot 5 \mathrm{H}_{2} \mathrm{O}$, the characteristic building units are isolated octahedra of $\left[\mathrm{Mg}\left(\mathrm{CO}_{3}\right)_{2}\left(\mathrm{H}_{2} \mathrm{O}\right)_{4}\right]^{2-}$ and $\left[\mathrm{Mg}\left(\mathrm{H}_{2} \mathrm{O}\right)_{6}\right]^{2+}$ (Liu et al., 1990).

The $\mathrm{MgO}$ octahedra in $\mathrm{MgCO}_{3} \cdot 6 \mathrm{H}_{2} \mathrm{O}$ are slightly distorted (Table 2).

The carbonate units are linked in a monodentate manner to two magnesium ions across the $\mathrm{O} 1$ atom. They are planar and exhibit $C_{2 v}$ symmetry, because the $\mathrm{C} 1-\mathrm{O} 1$ bond is a little longer than the $\mathrm{C} 1-\mathrm{O} 4$ bond. Furthermore, the $\mathrm{O} 1-\mathrm{C} 1-\mathrm{O} 4$ angle is a little narrower than the $\mathrm{O} 4-\mathrm{C} 1-\mathrm{O} 4{ }^{\text {iv }}$ angle (see Table 2 for numerical data and symmetry code).

The main building blocks are arranged in a sheet-like pattern, perpendicular to the $c$ axis (Figs. $5 a$ and $5 b$ ). Within a sheet, every second main building unit is shifted along the $\left[\frac{1}{2}, \frac{1}{2}, 0\right]$ direction and rotated by $90^{\circ}$. Consequently, a zigzag-

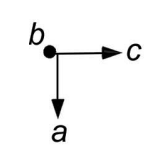

Figure 7

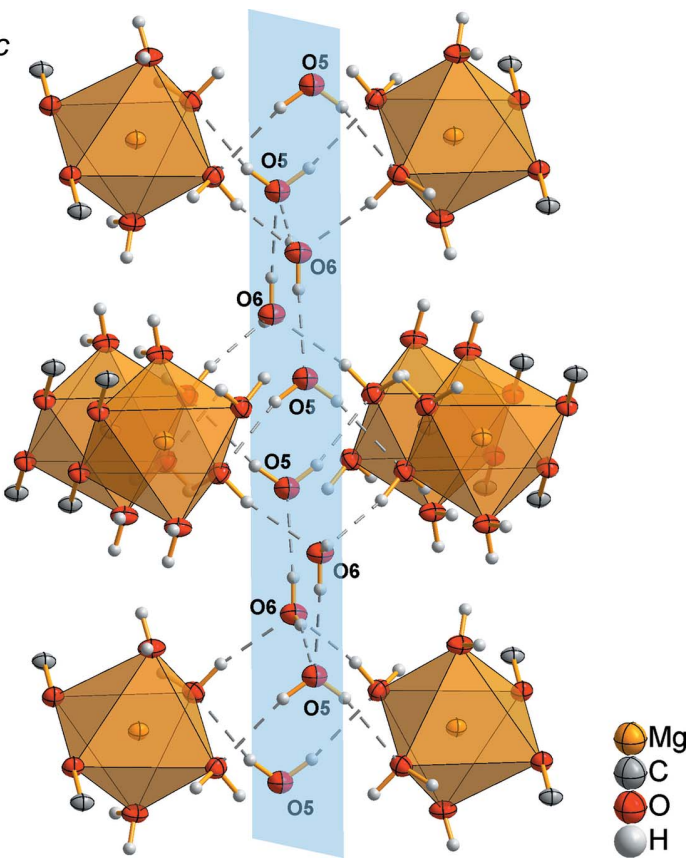

Part of the crystal structure of $\mathrm{MgCO}_{3} \cdot 6 \mathrm{H}_{2} \mathrm{O}$, showing the interlayer hydrogen bonds (dashed lines). The (001) plane is shown in blue. like stacking order results (Fig. 5c). The main building units in a sheet are linked by hydrogen bridging bonds (Fig. 6 and Table 3). The sheets are separated by layers of noncoordinating water molecules in the (001) plane.

All the atoms of the noncoordinating $\mathrm{H} 6 A-\mathrm{O} 6-\mathrm{H} 6 B$ molecule are located in the (001) plane, whereas in the H5$\mathrm{O} 5-\mathrm{H} 5^{\mathrm{i}}$ molecule, only the $\mathrm{O} 5$ atom is situated in this plane (Fig. 7). The (001) plane is also the mirror plane of this molecule. The noncoordinating water molecules are linked by hydrogen bridging bonds both in the (001) plane among themselves and with the $\mathrm{MgO}$ octahedra. Thus, the crystal structure is three-dimensional crosslinked (Fig. 7).

\subsection{Comparison with crystal structures of other carbonate hydrates of bivalent metal ions}

Other neutral carbonate hydrates of bivalent metal ions with a water content greater than five units per formula are only known for calcium $\left(\mathrm{CaCO}_{3} \cdot 6 \mathrm{H}_{2} \mathrm{O}\right)$ and nickel $\left(\mathrm{NiCO}_{3} \cdot-\right.$ $\left.5.5 \mathrm{H}_{2} \mathrm{O}\right)$. Like the title compound, these phases can be synthesized only at low temperatures of about $273.15 \mathrm{~K}$ and are transformed at room temperature to $\mathrm{CaCO}_{3}$ (Coleyshaw et al., 2003) and amorphous nickel carbonate (Bette et al., 2016; Rincke, 2018), respectively.

The crystal structure of $\mathrm{CaCO}_{3} \cdot 6 \mathrm{H}_{2} \mathrm{O}$ is significantly different from that of $\mathrm{MgCO}_{3} \cdot 6 \mathrm{H}_{2} \mathrm{O}$ for the very reason that the coordination number of the cation in $\mathrm{CaCO}_{3} \cdot 6 \mathrm{H}_{2} \mathrm{O}$ is eight and not six as in $\mathrm{MgCO}_{3} \cdot 6 \mathrm{H}_{2} \mathrm{O}$ (Dickens \& Brown, 1970; Hesse et al., 1983).

However, the radii of nickel and magnesium ions are very similar and actually the crystal structures of $\mathrm{NiCO}_{3} \cdot 5.5 \mathrm{H}_{2} \mathrm{O}$ and $\mathrm{MgCO}_{3} \cdot 6 \mathrm{H}_{2} \mathrm{O}$ exhibit similarities. Both crystal structures consist of isolated edge-linked pairs of $M\left(\mathrm{CO}_{3}\right)\left(\mathrm{H}_{2} \mathrm{O}\right)_{4}(M=$ $\mathrm{Mg}$ or $\mathrm{Ni})$, which are the main building units and are arranged in sheets, together with noncoordinating water molecules, perpendicular to the $c$ axis. The symmetry of $\mathrm{NiCO}_{3} \cdot 5.5 \mathrm{H}_{2} \mathrm{O}$ is lower; it crystallizes in the monoclinic group $P 2 / n$. As a consequence, there are two crystallographically different $\mathrm{Ni}$ atoms. In contrast to $\mathrm{MgCO}_{3} \cdot 6 \mathrm{H}_{2} \mathrm{O}$, in $\mathrm{NiCO}_{3} \cdot 5.5 \mathrm{H}_{2} \mathrm{O}$, the $\mathrm{NiO}$ octahedra of $\mathrm{Ni} 2$ are not rotated by $90^{\circ}$ (Bette et al., 2016).

\section{Conclusion}

A new neutral magnesium carbonate with the previously unknown high water content of six units per formula, i.e. $\mathrm{MgCO}_{3} \cdot 6 \mathrm{H}_{2} \mathrm{O}$, was produced by passing gaseous $\mathrm{CO}_{2}$ through an aqueous suspension of $\mathrm{MgO}$ and storing the filtered solution at $273.15 \mathrm{~K}$. The X-ray diffraction pattern and Raman spectra confirmed the formation of the new phase and its transformation to $\mathrm{MgCO}_{3} \cdot 3 \mathrm{H}_{2} \mathrm{O} . \mathrm{MgCO}_{3} \cdot 5 \mathrm{H}_{2} \mathrm{O}$ was not found in our study. Obviously, the formation conditions of magnesium carbonate hydrates depend on the concentration of the $\mathrm{MgO}$ suspension, the $\mathrm{CO}_{2}$ pressure, the temperature regime and the time of storage. Therefore, it would be useful to carry out further systematic investigations on the chemical kinetics of the formation of the magnesium carbonate hydrates. 
The crystal structure of $\mathrm{MgCO}_{3} \cdot 6 \mathrm{H}_{2} \mathrm{O}$ differs significantly from the other known magnesium carbonate hydrates, because the main building units are isolated pairs of edgelinked $\mathrm{Mg}\left(\mathrm{CO}_{3}\right)\left(\mathrm{H}_{2} \mathrm{O}\right)_{4}$ octahedra and free water molecules in the (001) plane, but it exhibits similarities to the nickel salt, $\mathrm{NiCO}_{3} \cdot 5.5 \mathrm{H}_{2} \mathrm{O}$ (hellyerite).

\section{References}

Bette, S., Rincke, C., Dinnebier, R. E. \& Voigt, W. (2016). Z. Anorg. Allg. Chem. 642, 652-659.

Brandenburg, K. (2017). DIAMOND. Crystal Impact GbR, Bonn, Germany.

Chaka, A. M. \& Felmy, A. R. (2014). J. Phys. Chem. A, 118, 74697488.

Coleyshaw, E. E., Crump, G. \& Griffith, W. P. (2003). Spectrochim. Acta A Mol. Biomol. Spectrosc. 59, 2231-2239.

Coppens, P. (1970). Crystallographic Computing, edited by F. R. Ahmed, S. R. Hall \& C. P. Huber, pp. 255-270. Copenhagen: Munksgaard.

Dickens, B. \& Brown, W. E. (1970). Inorg. Chem. 9, 480-486.

Frost, R. L. \& Palmer, S. J. (2011). Spectrochim. Acta A Mol. Biomol. Spectrosc. 78, 1255-1260.

Giester, G., Lengauer, C. L. \& Rieck, B. (2000). Mineral. Petrol. 70, 153-163.

Gloss, G. (1937). Dissertation. Friedrich-Wilhelms-University of Berlin, Germany.
Hänchen, M., Prigiobbe, V., Baciocchi, R. \& Mazzotti, M. (2008). Chem. Eng. Sci. 63, 1012-1028.

Hesse, K. F., Kueppers, H. \& Suess, E. (1983). Z. Kristallogr. 163, 227-231. Hill, R. J., Canterford, J. H. \& Moyle, F. J. (1982). Miner. Mag. 46, 453-457.

Hopkinson, L., Kristova, P., Rutt, K. \& Cressey, G. (2012). Geochim. Cosmochim. Acta, 76, 1-13.

Jauffret, G., Morrison, J. \& Glasser, F. P. (2015). J. Therm. Anal. Calorim. 122, 601-609.

Königsberger, E., Königsberger, L.-C. \& Gamsjäger, H. (1999). Geochim. Cosmochim. Acta, 63, 3105-3119.

Langmuir, D. (1965). J. Geol. 73, 730-754.

Liu, B., Zhou, X., Cui, X. \& Tang, J. (1990). Sci. China Ser. B, 33, 1350-1356.

Ming, D. W. \& Franklin, W. T. (1985). Soil Sci. Soc. Am. J. 49, 13031308.

Nestola, F., Kasatkin, A. V., Potapov, S. S., Chervyatsova, O. Y. \& Lanza, A. (2017). Miner. Mag. 81, 1063-1071.

Rincke, C. (2018). Dissertation, TU Bergakademie Freiberg. Freiberg, Germany.

Sheldrick, G. M. (2008). Acta Cryst. A64, 112-122.

Sheldrick, G. M. (2015). Acta Cryst. C71, 3-8.

Stoe \& Cie (2015). $X$-AREA and $X$-RED. Stoe \& Cie, Darmstadt, Germany.

Takahashi, G. \& Hokoku, E. S. (1927). Bull. Imp. Hyg. Lab. 29, 165-251.

Westrip, S. P. (2010). J. Appl. Cryst. 43, 920-925.

Yanateva, O. K. \& Rassonskaya, I. S. (1961). Zh. Neorg. Khim. 6, $1424-1430$ 


\section{supporting information}

Acta Cryst. (2020). C76, 244-249 [https://doi.org/10.1107/S2053229620001540]

\section{A new hydrate of magnesium carbonate, $\mathrm{MgCO}_{3} \cdot 6 \mathrm{H}_{2} \mathrm{O}$}

\section{Christine Rincke, Horst Schmidt and Wolfgang Voigt}

\section{Computing details}

Data collection: $X$-AREA (Stoe \& Cie, 2015); cell refinement: $X$-AREA (Stoe \& Cie, 2015); data reduction: $X$-RED (Stoe \& Cie, 2015); program(s) used to solve structure: SHELXS97 (Sheldrick, 2008); program(s) used to refine structure:

SHELXL2016 (Sheldrick, 2015); molecular graphics: DIAMOND (Brandenburg, 2017); software used to prepare material for publication: publCIF (Westrip, 2010).

Magnesium carbonate hexahysrate

Crystal data

$\mathrm{MgCO}_{3} \cdot 6 \mathrm{H}_{2} \mathrm{O}$

$M_{r}=192.42$

Orthorhombic, Pbam

$a=12.3564$ (18) $\AA$

$b=6.5165(7) \AA$

$c=9.9337(11) \AA$

$V=799.87(17) \AA^{3}$

$Z=4$

$F(000)=408$

\section{Data collection}

Stoe IPDS 2T diffractometer

Radiation source: sealed X-ray tube, $12 \times 0.4$ $\mathrm{mm}$ long-fine focus

Plane graphite monochromator

Detector resolution: 6.67 pixels $\mathrm{mm}^{-1}$

rotation method scans

Absorption correction: integration

(Coppens, 1970)

\section{Refinement}

Refinement on $F^{2}$

Least-squares matrix: full

$R\left[F^{2}>2 \sigma\left(F^{2}\right)\right]=0.029$

$w R\left(F^{2}\right)=0.085$

$S=1.18$

1143 reflections

83 parameters

0 restraints
$D_{\mathrm{x}}=1.598 \mathrm{Mg} \mathrm{m}^{-3}$

Mo $K \alpha$ radiation, $\lambda=0.71073 \AA$

Cell parameters from 9707 reflections

$\theta=2.7-27.0^{\circ}$

$\mu=0.24 \mathrm{~mm}^{-1}$

$T=200 \mathrm{~K}$

Prism, colorless

$0.7 \times 0.55 \times 0.15 \mathrm{~mm}$

$T_{\min }=0.694, T_{\max }=0.887$

8319 measured reflections

1143 independent reflections

965 reflections with $I>2 \sigma(I)$

$R_{\text {int }}=0.036$

$\theta_{\text {max }}=29.2^{\circ}, \theta_{\min }=3.3^{\circ}$

$h=-16 \rightarrow 16$

$k=-7 \rightarrow 8$

$l=-13 \rightarrow 11$

Primary atom site location: structure-invariant direct methods

Hydrogen site location: difference Fourier map

All $\mathrm{H}$-atom parameters refined

$w=1 /\left[\sigma^{2}\left(F_{\mathrm{o}}^{2}\right)+(0.0483 P)^{2}+0.1805 P\right]$

where $P=\left(F_{\mathrm{o}}{ }^{2}+2 F_{\mathrm{c}}{ }^{2}\right) / 3$

$(\Delta / \sigma)_{\max }<0.001$

$\Delta \rho_{\max }=0.23 \mathrm{e} \AA^{-3}$

$\Delta \rho_{\min }=-0.26 \mathrm{e} \AA^{-3}$ 


\section{Special details}

Geometry. All esds (except the esd in the dihedral angle between two 1.s. planes) are estimated using the full covariance matrix. The cell esds are taken into account individually in the estimation of esds in distances, angles and torsion angles; correlations between esds in cell parameters are only used when they are defined by crystal symmetry. An approximate (isotropic) treatment of cell esds is used for estimating esds involving l.s. planes.

Fractional atomic coordinates and isotropic or equivalent isotropic displacement parameters $\left(\AA^{2}\right)$

\begin{tabular}{lllll}
\hline & $x$ & $y$ & $z$ & $U_{\text {iso }} * U_{\text {eq }}$ \\
\hline $\mathrm{Mg} 1$ & 0.500000 & 0.000000 & $0.33923(5)$ & $0.01691(15)$ \\
$\mathrm{C} 1$ & $0.61245(11)$ & $0.3494(2)$ & 0.500000 & $0.0176(3)$ \\
$\mathrm{O} 1$ & $0.55574(8)$ & $0.18176(16)$ & 0.500000 & $0.0189(2)$ \\
$\mathrm{O} 2$ & $0.55982(7)$ & $0.20756(12)$ & $0.19775(8)$ & $0.02241(19)$ \\
O3 & $0.35722(6)$ & $0.16456(13)$ & $0.32879(9)$ & $0.0230(2)$ \\
O4 & $0.64098(6)$ & $0.43100(12)$ & $0.61217(8)$ & $0.0228(2)$ \\
O5 & $0.40386(10)$ & $0.3240(2)$ & 1.000000 & $0.0294(3)$ \\
O6 & $0.69316(10)$ & $0.0585(2)$ & 0.000000 & $0.0277(3)$ \\
H2A & $0.6079(17)$ & $0.167(3)$ & $0.1436(18)$ & $0.039(5)^{*}$ \\
H2B & $0.5913(18)$ & $0.305(3)$ & $0.252(3)$ & $0.057(6)^{*}$ \\
H3A & $0.3553(17)$ & $0.302(3)$ & $0.3545(18)$ & $0.043(5)^{*}$ \\
H3B & $0.2986(16)$ & $0.124(3)$ & $0.3454(16)$ & $0.033(4)^{*}$ \\
H6A & $0.755(2)$ & $0.062(4)$ & 0.000000 & $0.039(7)^{*}$ \\
H6B & $0.678(2)$ & $-0.071(5)$ & 0.000000 & $0.040(7)^{*}$ \\
H5 & $0.4421(17)$ & $0.310(3)$ & $0.9341(18)$ & $0.048(5)^{*}$ \\
\end{tabular}

Atomic displacement parameters $\left(\AA^{2}\right)$

\begin{tabular}{lllllll}
\hline & $U^{11}$ & $U^{22}$ & $U^{33}$ & $U^{12}$ & $U^{13}$ & $U^{23}$ \\
\hline $\mathrm{Mg} 1$ & $0.0166(2)$ & $0.0156(3)$ & $0.0185(2)$ & $-0.00105(17)$ & 0.000 & 0.000 \\
$\mathrm{C} 1$ & $0.0141(6)$ & $0.0140(6)$ & $0.0246(6)$ & $0.0010(5)$ & 0.000 & 0.000 \\
O1 & $0.0199(5)$ & $0.0155(5)$ & $0.0213(5)$ & $-0.0044(4)$ & 0.000 & 0.000 \\
O2 & $0.0227(4)$ & $0.0227(4)$ & $0.0219(4)$ & $-0.0016(3)$ & $0.0023(3)$ & $0.0024(3)$ \\
O3 & $0.0174(4)$ & $0.0188(4)$ & $0.0328(4)$ & $0.0004(3)$ & $0.0011(3)$ & $-0.0025(3)$ \\
O4 & $0.0230(4)$ & $0.0174(4)$ & $0.0281(4)$ & $-0.0031(3)$ & $-0.0031(3)$ & $-0.0031(3)$ \\
O5 & $0.0228(6)$ & $0.0363(7)$ & $0.0290(6)$ & $0.0013(5)$ & 0.000 & 0.000 \\
O6 & $0.0220(6)$ & $0.0280(6)$ & $0.0331(6)$ & $-0.0022(5)$ & 0.000 & 0.000 \\
\hline
\end{tabular}

Geometric parameters $\left(\AA,{ }^{\circ}\right)$

\begin{tabular}{|c|c|c|c|}
\hline $\mathrm{Mg} 1-\mathrm{O} 1$ & $2.1043(8)$ & $\mathrm{O} 3-\mathrm{H} 3 \mathrm{~A}$ & $0.93(2)$ \\
\hline $\mathrm{Mg} 1-\mathrm{O} 2$ & $2.0859(8)$ & $\mathrm{O} 3-\mathrm{H} 3 \mathrm{~B}$ & $0.788(19)$ \\
\hline $\mathrm{Mg} 1-\mathrm{O} 3$ & $2.0672(8)$ & $\mathrm{O} 5-\mathrm{H} 5$ & $0.812(18)$ \\
\hline $\mathrm{C} 1-\mathrm{O} 4$ & $1.2840(11)$ & $\mathrm{O} 5-\mathrm{H} 5^{\mathrm{i}}$ & $0.812(18)$ \\
\hline $\mathrm{C} 1-\mathrm{O} 1$ & $1.2978(17)$ & $\mathrm{O} 6-\mathrm{H} 6 \mathrm{~A}$ & $0.76(3)$ \\
\hline $\mathrm{O} 2-\mathrm{H} 2 \mathrm{~A}$ & $0.84(2)$ & $\mathrm{O} 6-\mathrm{H} 6 \mathrm{~B}$ & $0.87(3)$ \\
\hline $\mathrm{O} 2-\mathrm{H} 2 \mathrm{~B}$ & $0.92(2)$ & & \\
\hline $\mathrm{O} 3-\mathrm{Mg} 1-\mathrm{O} 2$ & $86.12(3)$ & $\mathrm{O} 3^{\mathrm{ii}}-\mathrm{Mg} 1-\mathrm{Mg} 1^{\mathrm{iii}}$ & $92.87(3)$ \\
\hline
\end{tabular}




$\begin{array}{llll}\mathrm{O} 2-\mathrm{Mg} 1-\mathrm{O} 2^{\mathrm{ii}} & 95.28(5) & \mathrm{O} 3-\mathrm{Mg} 1-\mathrm{Mg} 1^{\mathrm{iii}} & 92.87(3) \\ \mathrm{O} 3-\mathrm{Mg} 1-\mathrm{O} 1 & 91.46(4) & \mathrm{O} 2^{\mathrm{ii}}-\mathrm{Mg} 1-\mathrm{Mg} 1^{\mathrm{iii}} & 132.36(3) \\ \mathrm{O} 2-\mathrm{Mg} 1-\mathrm{O} 1 & 91.74(3) & \mathrm{O} 2-\mathrm{Mg} 1-\mathrm{Mg} 1^{\mathrm{iii}} & 132.36(3) \\ \mathrm{O} 1-\mathrm{Mg} 1-\mathrm{O} 1^{\mathrm{iii}} & 81.25(5) & \mathrm{O} 1^{\mathrm{iii}}-\mathrm{Mg} 1-\mathrm{Mg} 1^{\mathrm{iii}} & 40.63(2) \\ \mathrm{O} 4-\mathrm{C} 1-\mathrm{O} 4^{\mathrm{iv}} & 120.41(13) & \mathrm{O} 1-\mathrm{Mg} 1-\mathrm{Mg} 1^{\mathrm{iii}} & 40.63(2) \\ \mathrm{O} 4-\mathrm{C} 1-\mathrm{O} 1 & 119.79(6) & \mathrm{O} 4^{\mathrm{iv}}-\mathrm{C} 1-\mathrm{O} 1 & 119.79(6) \\ \mathrm{Mg} 1-\mathrm{O} 1-\mathrm{Mg} 1^{\mathrm{iii}} & 98.75(5) & \mathrm{C} 1-\mathrm{O} 1-\mathrm{Mg} 1^{\mathrm{iii}} & 130.58(2) \\ \mathrm{O} 3^{\mathrm{ii}}-\mathrm{Mg} 1-\mathrm{O} 3 & 174.25(5) & \mathrm{C} 1-\mathrm{O} 1-\mathrm{Mg} 1 & 130.58(2) \\ \mathrm{O} 3^{\mathrm{ii}}-\mathrm{Mg} 1-\mathrm{O} 2^{\mathrm{ii}} & 86.12(3) & \mathrm{Mg} 1-\mathrm{O} 2-\mathrm{H} 2 \mathrm{~A} & 118.3(12) \\ \mathrm{O} 3-\mathrm{Mg} 1-\mathrm{O} 2^{\mathrm{ii}} & 90.01(3) & \mathrm{Mg} 1-\mathrm{O} 2-\mathrm{H} 2 \mathrm{~B} & 101.9(14) \\ \mathrm{O} 3^{\mathrm{ii}}-\mathrm{Mg} 1-\mathrm{O} 2 & 90.01(3) & \mathrm{H} 2 \mathrm{~A}-\mathrm{O} 2-\mathrm{H} 2 \mathrm{~B} & 106.9(19) \\ \mathrm{O} 3^{\mathrm{ii}}-\mathrm{Mg} 1-\mathrm{O} 1^{\mathrm{iii}} & 91.46(4) & \mathrm{Mg} 1-\mathrm{O} 3-\mathrm{H} 3 \mathrm{~A} & 120.5(13) \\ \mathrm{O} 3-\mathrm{Mg} 1-\mathrm{O} 1^{\mathrm{iii}} & 92.91(4) & \mathrm{Mg} 1-\mathrm{O} 3-\mathrm{H} 3 \mathrm{~B} & 103.9(13) \\ \mathrm{O} 2^{\mathrm{ii}}-\mathrm{Mg} 1-\mathrm{O} 1^{\mathrm{iii}} & 91.74(3) & \mathrm{H} 3 \mathrm{~A}-\mathrm{O} 3-\mathrm{H} 3 \mathrm{~B} & 107(3) \\ \mathrm{O} 2-\mathrm{Mg} 1-\mathrm{O} 1^{i \mathrm{ii}} & 172.90(4) & \mathrm{H} 5-\mathrm{O} 5-\mathrm{H} 5^{\mathrm{i}} & 105(3) \\ \mathrm{O} 3^{\mathrm{ii}}-\mathrm{Mg} 1-\mathrm{O} 1 & 92.91(4) & \mathrm{H} 6 \mathrm{~A}-\mathrm{O} 6-\mathrm{H} 6 \mathrm{~B} & \\ \mathrm{O} 2^{\mathrm{ii}}-\mathrm{Mg} 1-\mathrm{O} 1 & 172.91(4) & & \end{array}$

Symmetry codes: (i) $x, y,-z+2$; (ii) $-x+1,-y, z$; (iii) $-x+1,-y,-z+1$; (iv) $x, y,-z+1$.

Hydrogen-bond geometry $\left(\AA,{ }^{\circ}\right)$

\begin{tabular}{lllll}
\hline$D-\mathrm{H} \cdots A$ & $D-\mathrm{H}$ & $\mathrm{H} \cdots A$ & $D \cdots A$ & $D-\mathrm{H} \cdots A$ \\
\hline $\mathrm{O} 5-\mathrm{H} 5 \cdots \mathrm{O} 2^{\mathrm{iv}}$ & $0.812(18)$ & $2.068(19)$ & $2.8545(12)$ & $162.9(18)$ \\
$\mathrm{O} 6-\mathrm{H} 6 B \cdots \mathrm{O} 5^{\mathrm{iii}}$ & $0.87(3)$ & $1.93(3)$ & $2.7662(19)$ & $161(2)$ \\
$\mathrm{O} 6-\mathrm{H} 6 A \cdots \mathrm{O} 5^{\mathrm{v}}$ & $0.76(3)$ & $1.99(3)$ & $2.7137(19)$ & $160(3)$ \\
$\mathrm{O} 3-\mathrm{H} 3 B \cdots \mathrm{O} 4^{\text {vi }}$ & $0.788(19)$ & $2.025(19)$ & $2.8055(12)$ & $170.7(18)$ \\
$\mathrm{O} 3-\mathrm{H} 3 A \cdots \mathrm{O} 4$ vii & $0.93(2)$ & $1.77(2)$ & $2.7001(12)$ & $174.1(18)$ \\
$\mathrm{O} 2-\mathrm{H} 2 B \cdots \mathrm{O} 4^{\text {iv }}$ & $0.92(2)$ & $1.70(2)$ & $2.5868(12)$ & $162(2)$ \\
$\mathrm{O} 2-\mathrm{H} 2 A \cdots \mathrm{O} 6$ & $0.84(2)$ & $1.91(2)$ & $2.7417(13)$ & $168.7(18)$
\end{tabular}

Symmetry codes: (iii) $-x+1,-y,-z+1$; (iv) $x, y,-z+1$; (v) $x+1 / 2,-y+1 / 2,-z+1$; (vi) $x-1 / 2,-y+1 / 2,-z+1$; (vii) $-x+1,-y+1,-z+1$. 